DOI :10.31357/fapsmst.2006.00491

\title{
MANUFACTURE OF VALUE ADDED PAPAYA PRODUCTS.
}

\author{
By \\ Manisha Harshani Wickramasinghe
}

A thesis submitted to the University of Sri Jayawardenepura for the award of the degree

Of

Master of Science

In

Food Science and Technology

Year 2006 


\section{DECLARATION}

The work in this thesis was carried out by me under the supervision of Prof.Athur

Bamunuarachchi ( Food Science \& Technology department , University of Sri

jayawardhenepura) and a report on a this has not been submitted in whole or in part to any University or any other institution for another Degree /Diploma.

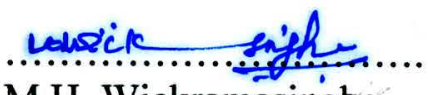

M.H. Wickramasinghe 
I Prof. Athur Bamunuarachchi hereby certify that the statement in the proceeding pages made by the candidate is true and that this thesis is suitable for submission for the University for the purpose of evaluation.

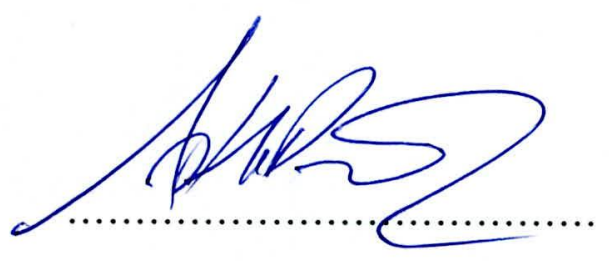

Signature

Supervisor

Prof. Athur Bamunuarachchi

CONSULTANT TO THE FOOD SCIENCE AND TECHNOLOGY PROGRAMME

DEPARTMENT OF FOOD SCIENCE AND TECHNOLOGY

UNIVERSITY OF SRI JAYAWARDENEPURA

GANGODAVILA, NUGEGODA

SRI LANKA. 


\section{DEDICATION}

AFFECTIONATELY DEDICATED

TO

MY LOVING PARENTS AND SISTERS 


\section{TABLE OF CONTENT}

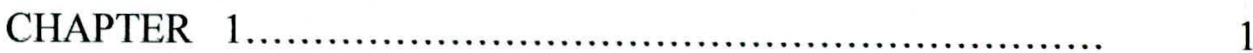

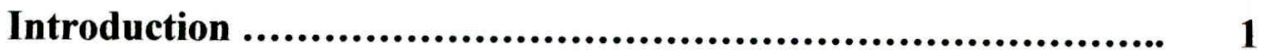

CHAPTETR 2 ................................................. 3

Literature Survey .................................................. 3

2.1. Common Introduction ....................................... 3

2.2. Pathology of Papaya.......................................... 5

2.3. Post Harvest losses of Papaya.................................. $\quad 5$

2.4. Horticultural Maturity Indices................................. 5

2.5. Pathological disorders of Papaya............................. 5

2.6. Retail outlet display Conditions .............................. 6

2.7. Optimum Storage Conditions................................. 7

2.8. Biochemical changes in Processing............................. 8

2.9. Composition of Papaya......................................... 9

2.10. Literature Survey of Products................................ 11

2.11. Other possible products................................... 16

2.12.Literatute on Process steps................................. 17

2.13. Sensory analysis........................................... 22

CHAPTER 3 ................................................. 23

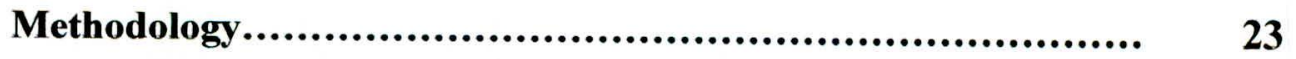

3.1. papaya pulp in bottle /Cups.................................. 23 


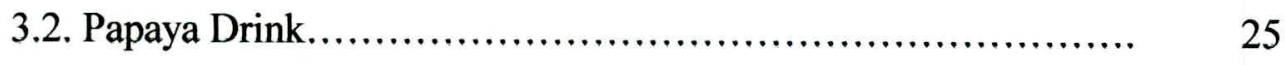

3.3. Osmotic Dehydration of Papaya pieces......................... 28

3.4. Papaya pieces in Sugar syrup................................. 31

3.5. Methodology of Analysis..................................... 33

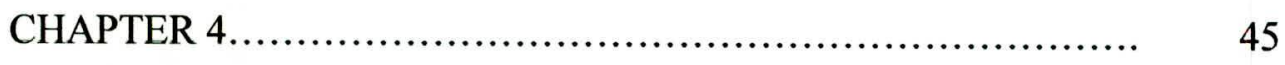

Results and Discussion........................................... 45

4.1. Results.................................................. 45

4.2.Discussion ................................................. 59

CHAPTER 5 .............................................. 62

Conclusions....................................................... 62

Reference:........................................................ 63

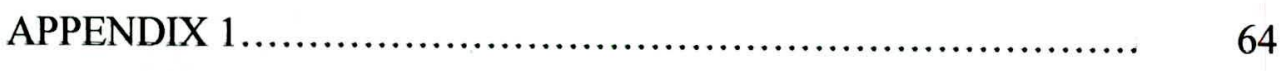

APPENDIX II................................................. 65

APPENDIX III............................................... 66 


\section{LIST OF FIGURES}

$\begin{array}{lll}\text { Figure } 1 \quad \text { Flow diagram Papaya pulp } & 24\end{array}$

Figure 2 Flow Diagram of Papaya drink 25

Figure $3 \quad$ Flow diagram of Osmotic Dehydrated Papaya pieces 27

Figure4 Flow diagram of Papaya pieces in juice 28

$\begin{array}{lll}\text { Figure 5 Papaya pulp } & 30\end{array}$

$\begin{array}{lll}\text { Figure } 6 & \text { Papaya Drink } & 31\end{array}$

Figure 7 Osmotic Dehydrated Papaya pieces 32

Figure 8 Papaya pieces in juice 33

$\begin{array}{lll}\text { Figure } 9 & \text { Drying Curve } & 48\end{array}$

Figure $10 \quad$ Changing of the brix of the pieces with time 50

Figure 11 Changing of the brix of the solution with time 50

Figure $12 \quad$ Standard curve for Ascorbic Acid 51 


\section{LIST OF TABLES}

Table 1 Post harvest losses of Papaya 5

$\begin{array}{lll}\text { Table } 2 \text { Respiration rates of Papaya } & 8\end{array}$

$\begin{array}{lll}\text { Table } 3 \text { Composition of Papaya } & 10\end{array}$

$\begin{array}{ll}\text { Table4 Composition of Papaya } & 10\end{array}$

Table $5 \quad$ Drying of Osmosis Papaya pieces 48

Table 6 Changing of the brix of the pieces 49

Table 7 Absorbance of Standard Ascorbic Acid 51

Table 8 Absorbance of Standard Ascorbic Acid 51

Table 9 Absorbance of Sample 53

Table $10 \quad$ Microbial Counts of the samples at the beginning 53

Table 11 Microbial Counts of the samples after 3 months 53

Table 12 Results of the Sensory analysis 55

Table 13 ANOVA Table 56 


\section{ABBREVIATIONS}

aw Water activity

SMS Sodium Metabi Sulphate

GMP Good Manufacturing Procedures

PDA Potato Dextrose Agar

UV Ultra Violet

A,A Ascobic Acid

TPC Total Plate Count

NP Not Detected

$\mathrm{H}_{2} \mathrm{O} \quad$ Water

C.HCl Concentrated hydrogen Chloride

AOAC Association of Official Analytical Chemists

SLS Sri Lanka Standards

$\mathrm{FPO}_{3} \quad$ Meta Phospheric Acid 


\title{
Development of value added Papaya Products
}

\section{By}

\section{M.H.Wicramasinghe}

\begin{abstract}
Most fruits and vegetables are seasonal. Due to improper post harvest handling there isn't a constant supply of fruit and vegetable to market. For this seasonal fruits need storage and preservation methods to extent shelf life. Osmotic dehydration, Dip in sugar syrup ( minimally processing), Making fruit drink, and making value added ready to eat pulp are some of the methods which can be use for preserve papaya. These can be done easily and less expensively. In cottage level also this can be done. That gives opportunity for farmers to preserve their fruit by themselves.

Fresh ripped yellow and red papaya were used for this study. For osmotic dehydrating use only sugar solutions at various drying time. For papaya pulp in bottles used heat treatment up to $80^{\circ} \mathrm{C}$ and exhausting before sealing. SMS 300ppm was added as preservative. Pulp in cups as a instant product only use heated fruit pulp and lemon juice. That was done variation on lemon juice. Papaya drink was prepared with using well ripped papaya, sugar and water. Water and sugar content was change to make different taste.
\end{abstract}

Vitamin C content, PH, Moisture, Water activity, Brix value of the sugar solution and pieces were measured according to the experiment.

Finally sensory evaluation was done by using nine point hedonic tables and were analyzed by ANOVA variance analysis.

According to results products all products were accepted by panelists xii 


\section{CHAPTER 1}

\section{Introduction}

Papaya is a common fruit grown in Sri- Lanka as well as other tropical countries. The origin of the plant is Eastern central America. It is a seasonal fruit . There are several varieties of Papaya available in the Sri Lankan market. Mainly pericarp colour of red/Orange to yellow . For this research, to prepare fruit drink used yellow coloured pericarp fruits and for other products used red

Papaya fruit contain higher amount of water ( $86.6 \%$ ) and carbohydrate content is 12.2 $\%$. Because of this higher water content fruit spoil easily. Therfore post harvest losses are high.

Preservation of fruit prevent post harvest losses and also makes the fruit available during off season.

Modern world people are keen on eating fruits, which helps to maintain good health and also they like to buy ready to eat food products. So food industry focus on this type of products with higher nutritional value . In the current food market there is a demand for minimally processed food products.

There are lot of preserving methods available. such as making juices, cordial, nectar, jams, jellies, chutney, candid papaya, osmotic dehydration some of them.

Mixed fruit juices are available in markets, but sole papaya drink can be introduce as a new product. Over ripped fruits, which can't be use for direct eating can be used for this purpose.

Pulp can be used as a major product for further preparations as well as a ready to eat product. Value added papaya pulp in cups can be introduced as a ready to eat desert. 
Osmotic dehydration is a traditional method used for food preservation. By using this method snack like products can be developed. This is an economical method. Due to the pressure gradient water lost from the fruit and the water activity is lowered, that inhibit the growth of micro organisms.

\section{Objectives}

*Minimize wastage of Papaya

*Give a new product by value addition to the traditional fruit.

*To increase shelf life of Papaya products.

*Study the variation of nutritional values ( Vitamin C, Carotene and Reducing Sugar content) in fresh Papaya and Value added products. 


\section{CHAPTER 2}

\section{Literature Survey}

\subsection{Common Introduction.}

Common name ; Papaya, Papaw, Paw Pa w

Botanical name ; Carica papaya L.

Native ;

Eastern Central America

\section{Distribution :}

Now it distributed through out the tropical areas in the word. Common fruit in Sri Lanka. Commonly grown in Hambantota, Moneragala, Anuradhapura, Polonnaruwa and most other districts.

\section{Tree:}

The Papaya tree is a perennial, usually not more than $7 \mathrm{~m}$ tall. Its stem is light green and hollow, less than $30 \mathrm{~cm}$ diameter. Plant is often single but may branch occasionally. Topped with a crown of leaves and fruit. When a leaf or fruit becomes senescent, it will eventually detach and leave a clear scar on the stem.

Leaves have hollow petioles $60 \mathrm{~cm}$ long or more and nearly round, deeply lobed blades up to $75 \mathrm{~cm}$ across.

Individual plant are usually unisexual, but hermaphrodite ( bisexual) flowers and trees also occur.

\section{Flower}

The male flowers are stalk less, $2-3 \mathrm{~cm}$ long, Funnel shape, with 10 stamens in each, and borne in slender panicles up to $1 \mathrm{~cm}$ long. 
The female flower are $3-5 \mathrm{~cm}$ long, solitary or in a small cluster in the leaf axils, with an ovary 2-3 cm and five fan-shaped stigma on top. Bisexual flowers have either 5 or 10 stamens.

\section{Fruit}

Fruits are melon like, elliptic, pear shaped, cylindrical. Pear shaped and hermaphroditic fruit is the moat common in markets. Length varying from $10-50 \mathrm{~cm}$. Weight from less than $100 \mathrm{~g}$ to $10 \mathrm{Kg}$. Peel thickness may vary. Thickness of flesh may vary from $1.5 \mathrm{~mm}$ to $4 \mathrm{~mm}$. A sweet juicy, yellow orange to red colour pericarp. This pericarp colour depend on cultivar. Central cavity containing small black seeds.

Plant flower within 6 month from sowing and fruit 4-5 month after flowering . Productivity decreased with age.

Quality characteristics and criteria

Size, shape, smooth skin and absence of blemishes are major characteristics.

\subsection{Pathology of Papaya}

Most common one is the ring spot virus attack.

The major post harvest diseases are anthracnosis and stem end rotting. Especially anthracnosis become a problem when fruit have $25 \%$ or more Skin yellowing.

This post harvest diseases increases after 4 weeks of storage. This happens due to mechanical and thermal injuries occur during handling and storage.

Another disease is Rhizopus rot disease. This occurs on cuticle disruption or breaking of cuticle and also on fruit fly punctures. When fruit is $40-60 \%$ yellow, this problem increases. 
Cercospora black spot is caused on skin .

Fruit fly infestation is common in Papaya.

\subsection{Post harvest losses of Papaya}

About $46 \%$ of Sri Lankan Papaya production losses in post harvest stage. $\%$ of losses

Producer

$6 \%$

Collector

$10 \%$

Wholesaler

$20 \%$

Retailer

$10 \%$

Total

$46 \%$

Table 1

\subsubsection{Treatments for post harvest diseases,}

These diseases are effectively controlled by dip in hot water at $49^{\circ} \mathrm{C}$ for 20 minutes.

Fungicide treatment.

Heat treatment and irradiation used for fruit fly disinfestations.

\subsection{Horticultural Maturity indices}

Minimum standard for soluble solid content is $11.5 \%$. So fruit should have started ripening before harvesting, as indicated by skin yellowing.

If the fruit is not mature, it contains low sugar content and poor ripening.

\subsection{Physiological Disorders of Papaya available in market}

These are non pathological disorders.

There are number of disorders, 